\title{
Comparative Assessment of Haematopoietic Potential of Ethanolic Extract of Telfairia occidentalis and Talinum triangulare Leaves in Wistar Rats
}

\author{
Augustine I Airaodion ${ }^{*}$, Uloaku Ogbuagu' ${ }^{1}$, John A Ekenjoku ${ }^{2}$ and Emmanuel 0 Ogbuagu ${ }^{2}$ \\ ${ }^{1}$ Department of Biochemistry, Federal University of Technology, Owerri, Imo State, Nigeria \\ ${ }^{2}$ Department of Pharmacology and Therapeutics, Abia State University, Uturu, Nigeria \\ *Corresponding Author: Augustine I Airaodion, Department of Biochemistry, Federal University of Technology, Owerri, Imo State, \\ Nigeria.
}

Received: August 29, 2019; Published: September 10, 2019

\begin{abstract}
Several researchers have reported studies on the consumption of Telfairia occidentalis leaves for its haematopoietic properties but there is a dearth of information on the consumption of Talinum triangulare leaves for its haematopoietic potentials. This study is designed to compare the haematopoietic properties of T. occidentalis leaves with that of T. triangulare leaves. Both plants were purchase from a market in Orita-Challenge area of Ibadan, in Ibadan South West local government Area, Nigeria. The leaves were air dried at room temperature in an open laboratory. They were milled into powder and extracted using soxhlet apparatus and ethanol as the solvent. The ethanol was evaporated in a rotary evaporator at $35 \mathrm{oC}$ with a yield of $1.78 \mathrm{~g}$ which represents a percentage yield of $7.12 \%$ for the leaves of $T$. occidentalis while $T$. triangulare leaves yielded $2.76 \mathrm{~g}$ which represents a percentage yield of $11.04 \%$. Fifteen Wistar rats were used in this study. They were grouped into three of five rats each. Group 1 served as control, group 2 and 3 were treated with ethanolic extracts of T. occidentalis and T. triangulare respectively for twenty-eight days. Analyses of the haematological parameters were determined using standard methods. The result showed that both plants increased haematological parameters when compared with control animals. However, the packed cell volume, red blood cell and platelets of animals treated with $T$. triangulare leaves were significantly higher than those treated with T. occidentalis leaves at $\mathrm{p}<0.05$. It is obvious from this study that consumption of the both plants enhanced haematopoiesis and would therefore improve the physiological and nutritional status of its consumers. However, T. triangulare leaves is a better haematopoietic agent than T. occidentalis leaves. The study has further justified the ethnobotanical use of both plants as a blood tonic and antianemic. Instead of focusing on the leaves of T. occidentalis for its haematopoietic potentials, the leaves of $T$. triangulare could be a better substitute.
\end{abstract}

Keywords: Telfairia occidentalis; Talinum triangulare; Haematopoietic Properties; Ethanolic Leaf Extracts; Anaemia

\section{Introduction}

Vegetables are the cheapest and most available sources of protein, vitamins, minerals and essential amino acids [1]. They are added as supplements to provide useful and correct proportions of nutrients and some have medicinal properties useful for the invalids and convalescences. Consumable vegetables are those plants whose leaves or aerial parts have been integrated into a food chain for consumption over a large span of time. They are highly recommended because they have a relatively high nutritional value and their consumption gives daily food intake and adding flavour to the diet. Vegetables constitute essential components of the diet, by contributing nutrients and food properties that are important to human health. A healthy circulatory system could gain from a balanced diet rich in adequate fruits and vegetables [2]. Epidemiological proofs support a high positive relationship between intake of fruits and vegetables with cardiovascular health $[3,4]$. Increased awareness on the usefulness of vegetable inclusions in human food has enhanced their consumption as part of daily diet. Consumption of vegetables has been associated with a reduction in the incidences of chronic diseases of lifestyle such as cardiovascular diseases, coronary heart diseases and various types of cancer.

Telfairia occidentalis (Fluted pumpkin) is one of the popular and widely grown vegetable crops in Nigeria mainly in the eastern part, mid-western areas of Edo and Delta States and to an appreciable degree in the south western states. It is often known as "ugu" [5]. It is a herb grown majorly for its succulent fresh leaves and shoots which served as vegetables [6]. The crop is cultivated beside trees, walls, fences and structures on which the shoots are allowed to climb because it is a high-climbing perennial crop. It may be staked or left to creep on the floor [7]. 


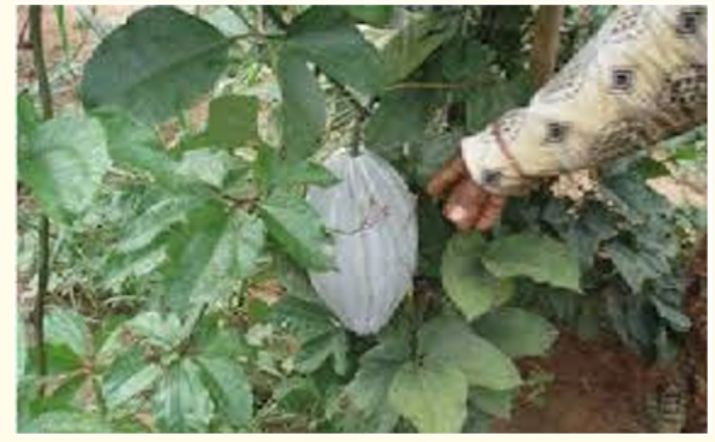

Figure 1: Telfairia occidentalis Plant with its seed pod [8].

T. occidentalis is a crop eaten for its medicinal benefits. Airaodion., et al. [9] has reported the phytochemical content and antioxidant potential of its leaves. The presence of therapeutic active agents could be the reason for the analgesic activity of T. occidentalis [10]. T. occidentalis leaves has been reported to possess pro-fertility potentials that could be harnessed in fish fingerling production by hatchery farmers [11] while Kuku., et al. [12] reported that T. occidentalis seeds could positively affect metabolism of nutrient and the growth performance in animals. The medicinal benefits of T. occidentalis have been reported on hematological indices of starter broilers [13], concentration of hemoglobin and packed cell volume [14], lipid peroxidation amelioration and cardiovascular disease reduction [15]. Its hepatoprotective effects on the liver have been reported [16], while Ajani and Akinyemi [17] highlighted its therapeutic efficacy on induced benign prostatic hyperplasia. Airaodion., et al. [8] reported the haemolytic effect of its leaves and seed.

Talinum triangulare (Jacq.) Willd (Portulacaceae) is a caulescent, perennial herb growing to a height of $80-100 \mathrm{~cm}$. It is often referred to as Waterleaf due to of its high moisture content of almost $90.8 \%$ of edible leaf [18]. In Nigeria, the plant is known by different names: Gbure in Yoruba, Nteoka/inene in Igbo, and Alenyruwa in Hausa language. It is widely grown in most of the humid tropical countries such as West Africa, Asia and South America [19]. It thrives well under shade and in cloudy weather. Waterleaf is relatively tolerant to drought conditions as they tend to adopt a crassulacean acid metabolism (CAM) pathway, thus resulting in efficient utilization of available moisture, carbon dioxide assimilation during night and increased growth [18]. The plant is rich in total lipids, crude protein, essential oils, flavonoids, cardiac glycosides and polyphenols [20]. Preliminary phytochemical investigation on T. triangulare revealed the presence of omega-3-fatty acids and high concentrations of essential nutrients like minerals (such as magnesium, potassium and calcium), soluble fibres (such as pectin) and vitamins which are basic requirement for growth and development [19].

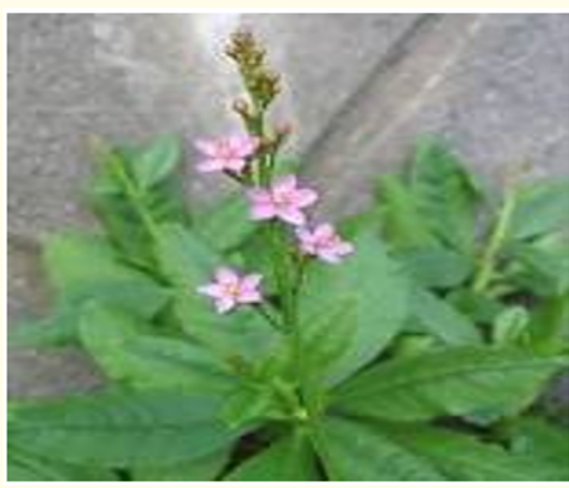

Figure 2: Talinum triangulare Plant [19].

The plant has been reported to have remarkable antioxidant potential [21] and high kaempferol composition [22]. Waterleaf is a mucilaginous vegetable rich in oxalate and high saponins content. Cooking or blanching could remove most of the soluble oxalate. In addition, the leaves are used as condiment, sauce, spice, softening of soups and for flavouring in foods [23]. T. triangulare leaves have been reported to be active in the management of cardiovascular diseases such as stroke and obesity [24]. According to folk medicine waterleaf has been reported to be effective in the management of polyuria [25], internal heat, measles [18], gastrointestinal disorders [26], hepatic ailments and cancer [21]. Furthermore, Airaodion., et al. [27] has reported its hypoglycemic and hypolipidaemic activities in Wistar rats. The preventive and therapeutic activities of methanolic extract of $T$. triangulare leaves against ethanol-induced oxidative stress in Wistar rats have also been reported [28]. Another study by Airaodion., et al. [29] evaluated its haematopoietic potential in Wistar rats. Traditionally, there is a high focus on the leaves of T. occidentalis for its haematopoietic benefit but consumption of T. triangulare leaves for its haematopoietic potential has not gain maximum attention. This present study therefore sought to compare the haematopoietic potentials of both plants.

\section{Materials and Methods}

\section{Collection and Extraction of Plant Materials}

Both plants were purchase from a local market in Orita-Challenge area of Ibadan, Nigeria and were identified by a botanist. The leaves were carefully removed from the stem and washed in running water to remove contaminants. They were air dried at room temperature in an open laboratory space until they were completely dried. They were milled into powder using an electronic blender (Moulinex). The extraction was done using soxhlet apparatus and ethanol as the solvent according to the method described by Airaodion., et al [30]. About $25 \mathrm{~g}$ of the powder was packed into the thimble of the soxhlet extractor and $250 \mathrm{~mL}$ of ethanol was added to a round bottom flask, which was attached to the soxhlet extractor and condenser on a heating mantle. The solvent was heated us- 
ing the heating mantle and began to evaporate moving through the apparatus to the condenser. The condensate dripped into the reservoir housing the thimble containing the sample. Once the level of the solvent reached the siphon, it poured back into the round bottom flask and the cycle began again. The process was allowed to run for about 18 hours. Once the process was completed, the ethanol was evaporated in a rotary evaporator at $35 \mathrm{oC}$ with a yield of $1.78 \mathrm{~g}$ which represents a percentage yield of $7.12 \%$ for the leaves of $T$. occidentalis while T. triangulare leaves yielded $2.76 \mathrm{~g}$ which represents a percentage yield of $11.04 \%$. The extracts were preserved in the refrigerator for further analysis.

\section{Experimental design}

Fifteen adult male Wistar rats weighing 150 - $170 \mathrm{~g}$ were purchased from the Central Animal House, College of Medicine, University of Ibadan, Nigeria. They were allowed to acclimatize for seven (7) days during which they were fed ad libitum with standard feed and drinking water and were housed in clean cages placed in wellventilated housing conditions (under humid tropical conditions) throughout the experiment. All the animals received humane care according to the criteria outlined in the 'Guide for the Care and Use of Laboratory Animals' prepared by the National Academy of Science and published by the National Institute of Health. They were divided into three groups of five rats each. Animals in group 1 were administered saline solution (control group); those in group 2 were administered T. occidentalis leaf extract while those in group 3 were administered T. triangulare leaf extract. The administration was done 12 hourly for twenty-eight days at $100 \mathrm{mg} / \mathrm{kg}$ body weight via oral route since the plant is consumed orally. At the end of the twenty-eight days' treatment, animals were fasted overnight and anaesthetized using diethyl ether. Blood samples were collected by cardiac puncture into heparinized bottles. The blood samples were centrifuge for 10 minutes using a bench-top centrifuge (Centromix) and the supernatant plasma was then used for the determinations of the haematological parameters.

\section{Determination of haematological parameters}

The red blood cells (RBC) and white blood cells (WBC) counts were determined by the improved Neubauer haemocytometer method. The haemoglobin ( $\mathrm{Hb})$ concentration was determined according to Jain [31], using the cyanomethaemoglobin method. The packed cell volume (PCV) was determined by the microhaematocrit method described by Dacie and Lewis [32]. Differential lecukocyte count was determined by Schilling method [33]. Mean corpuscular volume (MCV), mean corpuscular haemoglobin (MCH) and mean corpuscular haemoglobin concentration (MCHC) were computed according to Jain [31].

\section{Statistical analysis}

Data were analyzed using Graph Pad Prism. Results were presented as Mean \pm standard deviation. One way analysis of variance (ANOVA) was used for comparison of the means followed by Tukey's (HSD) multiple comparison test. Differences between means were considered to be significant at $\mathrm{p}<0.05$.

\section{Results and Discussion}

Anaemia increases in prevalence and severity as renal activity declines, it becomes much more pronounced at decreased glomerular filtration rate. Depending on the severity, some of the symptoms of anaemia may include: weakness, loss of appetite, fatigue, pale skin, low haematocrit and hemoglobin in a RBC etc. likely factors that can contribute to anaemia in serve kidney diseases include shortened red cell life span, blood loss, vitamin deficiencies, iron deficiency, the "uremic milieu," erythropoietin (EPO) deficiency, and inflammation [34]. However, the typical "anaemia of chronic renal insufficiency" is a result of a decreased production of red blood cells by the bone marrow. This defect in red blood cell production is largely explained by the inability of the failing kidneys to secrete hormone erythropoietin. This hormone is a necessary stimulus for normal bone marrow to produce red blood cells.

The affordability of some herbs over expensive orthodox drugs for the management of some diseases among non-industrialized societies is rapidly becoming revolutionized. In some countries, it has been integrated into the health scheme despite advances in orthodox medicine. It is believed that the herbal products if administered in the right form and dosage are less harmful than synthetic drugs, which often elicit some adverse effects [35]. Several researchers have reported the beneficial effect of T. occidentalis leaves especially its haemoatopoeitic effect but there is a dearth of information on the haematopoietic benefit of $T$. triangulare leaves. This study is therefore aimed at comparing the effect of both leaves on the haematological parameters of Wistar rats.

In this study, a significant increase was observed when the blood levels of erythrocyte parameters (packed cell volume (PCV), haemoglobin ( $\mathrm{Hb}$ ), red blood cell (RBC), Mean Corpuscular Volume (MCV)) of control animals were compared with animals treated with leaf extracts of $T$. occidentalis and T. triangulare respectively at $p<0.05$ as presented in Table 1 . This is an indication that there may be increased production of red blood cells therefore, suggesting the non-toxic nature of both the leaves to red blood cells at this period of administration. This might be due to the presence of phytochemical content and antioxidant potential of the T. occidentalis leaves as reported by Airaodion., et al [9]. Similarly, Swarna and Ravindhran [36] and Liao., et al. [37] have reported that T. triangulare leaves are rich in phytochemicals and antioxidants respectively. Furthermore, Airaodion., et al. [28] had previously reported that $T$. triangulare leaves acts as preventive and therapeutic agent against ethanol-induced oxidative stress in Wistar rats due to its antioxidant potential. In the same vein, Airaodion., et al. [38] in another study reported the pharmacotherapeutic effect of T. occidentalis leaves on glycemic and lipidemic indexes of alloxan-induced diabetic rats due to its antioxidant potential. Their actions on blood levels of erythrocyte parameters might also be attributed to their antioxidant activities. 
Comparative Assessment of Haematopoietic Potential of Ethanolic Extract of Telfairia occidentalis and Talinum triangulare Leaves in Wistar Rats

\begin{tabular}{|c|c|c|c|}
\hline Parameters & Control & T. occidentalis Extract & T. triangulare Extract \\
\hline PCV (\%) & $37.083 .45^{\mathrm{a}}$ & $45.093 .14^{\mathrm{b}}$ & $48.212 .43^{c}$ \\
\hline $\mathrm{Hb}(\mathrm{g} / \mathrm{dL})$ & $9.410 .47^{\mathrm{a}}$ & $12.701 .08^{\mathbf{b}}$ & $13.111 .84^{\mathbf{b}}$ \\
\hline $\mathrm{RBC}\left(\mathrm{X} 10^{12} / \mathrm{L}\right)$ & $6.790 .67^{\mathrm{a}}$ & $10.451 .44^{\mathrm{b}}$ & $13.742 .27^{\mathrm{c}}$ \\
\hline $\mathrm{MCV}(\mathrm{FL})$ & $54.656 .80^{\mathrm{a}}$ & $43.133 .99^{\mathbf{b}}$ & $44.244 .33^{\mathbf{b}}$ \\
\hline MCH (pg) & $14.871 .19^{\mathrm{a}}$ & $12.152 .18^{\mathrm{a}}$ & $12.791 .39^{\mathrm{a}}$ \\
\hline MCHC (g/dL) & $25.382 .74^{\mathrm{a}}$ & $30.173 .09^{b}$ & $31.313 .28^{\mathrm{b}}$ \\
\hline
\end{tabular}

Table 1: Effect of Ethanolic Extracts of T. occidentalis and T. triangulare Leaves on Erythrocyte Parameters in Wistar Rats after 28 days of Administration.

Values are presented as Mean \pm standard deviation, where $n=5$. Values with different superscript along the same row are significantly different at $\mathrm{p}<0.05$.

LEGEND: PCV = Packed Cell Volume; Hb = Haemoglobin; RBC = Red Blood Cell; MCV = Mean Corpuscular Volume; $\mathrm{MCH}=$ Mean Corpuscular Haemoglobin; MCHC = Mean Corpuscular Haemoglobin Concentration.

It is therefore possible that consumption of both plants by humans can help prevent anaemia especially in menstruating and pregnant women. It is on record that values of red blood cells and associated parameters lower than normal ranges are suggestive of anemia while higher values are indicative of polycythemia [41], therefore, it could mean that the 28-day treatment with both plants lack the propensity to induce anemia or polycythemia. The significant elevation observed in the PCV and RBC of animals treated with T. triangulare leaves when compared with those treated with T. occidentalis leaves for 28 days might be an indication that
T. triangulare leaves are better haematopoietic agents than T. occidentalis leaves.

The results of this study revealed a significant difference in the white blood cells parameters of control animals when compared with those treated with both plant extracts respectively at $\mathrm{p}<0.05$ as presented in Table 2 . White blood cells, platelet, neutrophil, and lymphocytes are used to provide useful information for diagnosis in routine clinical evaluation of the state of health of a patient. Variations in the haematological parameters have a higher tendency become toxic in human [42].

\begin{tabular}{|l|c|c|c|}
\hline \multicolumn{1}{|c|}{ Parameters } & Control & T. occidentalis Extract $^{\text {T. triangulare } \text { Extract }}$ \\
\hline WBC $\left(X 10^{9} / \mathrm{L}\right)$ & $13.021 .96^{\mathrm{a}}$ & $20.100 .72^{\mathrm{b}}$ & $19.941 .33^{\mathrm{b}}$ \\
\hline Lymphocyte (\%) & $38.086 .79^{\mathrm{a}}$ & $57.105 .42^{\mathrm{b}}$ & $53.385 .44^{\mathrm{b}}$ \\
\hline Neutrophil (\%) & $61.986 .79^{\mathrm{a}}$ & $32.905 .42^{\mathrm{b}}$ & $58.933 .48^{\mathrm{a}}$ \\
\hline Platelet $\left(\mathrm{X} 10^{9} / \mathrm{L}\right)$ & $418.021 .96^{\mathrm{a}}$ & $413.100 .72^{\mathrm{a}}$ & $435.243 .04^{\mathrm{b}}$ \\
\hline
\end{tabular}

Table 2: Effects of Ethanolic Extracts of T. occidentalis and T. triangulare Leaves on White Blood Cells Parameters and Platelets in Wistar Rats after 28 days of Administration.

Values are presented as Mean \pm standard deviation, where $n=5$. Values with different superscript along the same row are significantly different at $p<0.05 . \mathrm{WBC}=$ White Blood Cell.

The increase in WBC and lymphocyte counts may be due to the presence of anti-nutritional compounds such as saponins, flavonoids and steroid glucosides in in both plants [9,36]. It has been emphasized that the high percentage of WBC especially lymphocytes are associated with the ability of the animals to perform well under very stressful conditions [43]. This increase in the WBC and percentage lymphocyte counts suggests that the phytochemical compounds present in the extracts elicited stress responses. The effect of both extracts on the WBC count might be due to their glycoside contents. This compound has been reported to possess anti-inflammatory property and could cause inflammation leading to pathological states like malaria, bacterial infection and liver diseases [44]. This might also imply that both plants might strengthen the immune system through many cytokines regulation.
The result on reduced level of neutrophil count caused by both extracts may be one of the reasons for the benign ethnic neutropenia experienced by Africans. This might be an indication that the body's ability to attack and destroy invading viruses, bacteria and other injurious agents (Phagocytosis) has been compromised [45]. However, this decrease was not significant in animals treated with $T$. triangulare leaves. This could suggests that $T$. triangulare leaves have a better ability to attack and destroy invading bacteria, viruses and other injurious agents (Phagocytosis) than T. occidentalis leaves.

Interestingly, animals treated with T. triangulare leaves has an increased platelet count when compared with those treated with T. occidentalis leaves and control. This may be an indication that leaf extract of T. occidentalis has no effect on the actions of platelet 
activating factor (PAF) and thus on the blood clotting potentials. It could also be an indication that it does not has the potential to stimulate thrombopoietin production with the hemostatic capability of the blood maintaining the status quo since platelets mediate in the blood-clotting mechanism, whereas, T. triangulare leaves have the propensity to stimulate the actions of platelet activating factor (PAF) and thus the blood clotting potentials as well as thrombopoietin production [46]. This is suggestive that leaf extract of $T$. triangulare is better in thrombopoietin production as well as blood clotting potentials than the leaf extract of T. occidentalis.

\section{Conclusion}

It is obvious from this study that consumption of the both plants enhanced haematopeisis and would therefore improve the physiological and nutritional status of its consumers. However, $T$. triangulare leaves is a better haematopoietic agent than T. occidentalis leaves. The study has further justified the ethnobotanical use of both plants as a blood tonic and antianemic. Instead of focusing on the leaves of T. occidentalis for its haematopoietic properties, the leaves of T. triangulare is a better substitute.

\section{Conflict of Interest}

Authors wish to declare that no conflict of interest exist in this publication.

\section{Bibliography}

1. Okafor JC. "Horticultural promising indigenous wild plant species of the Nigerian forest zone". Acta Horticulturae 123 (1983): 165-176.

2. Zheng J., et al. "Effects and mechanisms of fruit and vegetable juices in cardiovascular diseases". International Journal of Molecular Sciences 18 (2017): E555.

3. Sikand G., et al. "Impact of functional foods on prevention of cardiovascular disease and diabetes". Current Cardiology Reports 17 (2005): 39.

4. Trude A., et al. "Patterns of food consumption are associated with obesity, self-reported diabetes and cardiovascular disease in five American Indian communities". Ecology of Food and Nutrition 54.5 (2015): 437-454.

5. Okoli BE and Mgbeogu CM. "Fluted Pumpkin Telferia Occidentalis: West African Vegetables". Economic Botany 3.7 (1982): 145-149.

6. Akoroda MO. "Ethnobotany of Telfairia occidentalis (Cucurbitaceae) among Igbos of Nigeria". Economic Botany 44.1 (1988): 29-39.

7. NIHORT. "National Horticultural Research Institute guide to the Production of some Vegetables". Extension Guide 8 (1986): 15-18.

8. Airaodion AI., et al. "Investigation of Haemolytic Properties of Ethanolic Leaf and Seed extracts of Telfairia occidentalis in Wistar Rats". International Journal of Research and Reports in Hematology 2.3 (2019):1-8.
9. Airaodion AI., et al. "Evaluation of Phytochemical Content and Antioxidant Potential of Ocimum gratissimum and Telfairia occidentalis Leaves". Asian Journal of Research in Medical and Pharmaceutical Sciences 7.1 (2019):1-11.

10. Okokon JE., et al. "Chemical constituents and analgesic activity of Telfaria occidentalis". Phytopharmn 3.2 (2012): 359-366.

11. Dada A and Ejete-Iroh VC. "Dietary fluted pumpkin (Telfairia occidentalis) improves reproductive indices in male African catfish (Clariasgariepinus) broodstock". The Journal of Agricultural Science 7.7 (2015): 228-234.

12. Kuku A., et al. "Processing of fluted pumpkin seeds, Telfairia occidentalis (Hook F) as it affects growth performance and nutrient metabolism in rats". African Journal of Food, Agriculture, Nutrition and Development 14.5 (2014):1992-2014.

13. Onu PN. "Effect of aqueous extract of Telfairia occidentalis leaf on the performance and haematological indices of starter broilers". Veterinary Sciences 3.2 (2012):25-31.

14. Obeagu EI., et al. "Haematological effects of fluted pumpkin (Telfairia occidentalis) leaves in rats". International Journal of Life science and Pharma Research 3.1 (2014): 172-182.

15. Daramola 00., et al. "Effects of methanol extract of Telfairia occidentalis seed on serum lipid profile, biochemical and antioxidant activity in female Wistar rats". European Journal of Medical Physics 15.2 (2016):1-8.

16. Ekpenyong CE., et al. "Phytochemistry and Toxicity studies of Telfairia occidentalis aqueous leaf extract on liver biochemical indices in Wistar rats". The American Journal of the Medical Sciences 2.5 (2012):103-110.

17. Ajani RS and Akinyemi AR. "Telfairia occidentalis leaf and seed extract as possible preventive and therapeutic agents for induced benign prostatic hyperplasia". European Journal of Medicinal Plants 12.1 (2016):1-11.

18. Fontem DA and Schippers RR. "Talinum triangulare (Jacq.) Willd [Internet] Record from Protabase: Grubben GJH, Denton OA (Editors), PROTA (Plant Resources of Tropical Africa/Ressources ve'ge'tales de l'Afrique tropicale), Wageningen, Netherlands (2014).

19. Ezekwe MO., et al. "Beneficial influence of Purslane and Waterleaf supplementation on cardiovascular disease risk in humans". FASEB Journal 16.4 (2002): A639.

20. Sridhar R and Lakshminarayana G. "Lipid Classes, Fatty Acids and Tocopherols of Leaves of Six Edible Plant Species". Journal of Agricultural and Food Chemistry 41 (1993):61-63.

21. Liang D., et al. "Studies on the antioxidant and hepatoprotective activities of polysaccharides from Talinum triangulare". Journal of Ethnopharmacology 136.2 (2011):316-321.

22. Andarwulan N., et al. "Flavonoid content and antioxidant activity of vegetables from Indonesia". Food Chemistry 121.4 (2010):1231-1235. 
23. Mbang A., et al. "Evaluation of the antioxidant activity and lipid peroxidation of the leaves of Vernonia amygdalina". Journal of Complementary and Integrative Medicine 5 (2008).

24. Adewunmi AO and Sofowora EA. "Preliminary screening of some plant extracts for molluscidal activity". Planta Medica 39 (1980): 57-82.

25. Khare CP. "Indian medicinal plants An Illustrated dictionary". Springer publication. New York (2007): 643.

26. Mensah JK., et al. "Phytochemical, nutritional and medical properties of some leafy vegetables consumed by Edo people of Nigeria". African Journal of Biotechnology 7 (2008): 23042309.

27. Airaodion AI., et al. "Hypoglycemic and hypolipidaemic effect of methanolic extract of Corchorus olitorius leaves in Wistar rats". Asian Plant Research Journal 7.6 (2019):1-12.

28. Airaodion AI., et al. "Preventive and therapeutic activities of methanolic extract of Talinum triangulare leaves against ethanol-induced oxidative stress in Wistar rats". International Journal of Bio-Science and Bio-Technology 11.7 (2019):85-96.

29. Airaodion AI., et al. "Haematopoietic Potential of Ethanolic Leaf extract of Talinum triangulare in Wistar Rats". Asian Journal of Research in Biochemistry 5.2 (2019):1-7.

30. Airaodion AI., et al. "Hypoglycemic and hypolipidaemic effect of methanolic extract of Corchorus olitorius leaves in Wistar rats". Asian Plant Research Journal 7.6 (2019):1-12.

31. Jain NC. "Schalm's Veterinary Haematology 4th edition. Lea and Fabiger, Philadelphia (1986).

32. Dacie JV and Lewis SM. "Practical haematology, 7th edition ELBS with Churchill Livingston, England (1991): 37-85.

33. Mitruka BM and Rawnsley H. "Clinical, biochemical and haematological references values in normal experimental animals". Masson Publishing USA Inc (1977): 53-54.

34. Nelson RG. "Diabetic Renal Disease in Transitional and Disadvantaged Populations". Nephrology 6 (2001): 9-17.

35. Adisa WA., et al. "Testicular damage in Telfairia occidentalis extract treated Wistar rats". American Journal of Medical and Biological Research 2.2 (2014): 37-45.

36. Swarna J and Ravindhran R. "Pharmacognostical and phytochemical evaluation of Talinum triangulare (jacq.) Willd". International Journal of Pharmacy and Pharmaceutical Sciences 5.2 (2013): 1-8.

37. Liao DY., et al. "Antioxidant activities and contents of flavonoids and phenolic acids of Talinum triangulare extracts and their immunomodulatory effects". Journal of Food and Drug Analysis 23.2 (2015):294-302.

38. Airaodion AI., et al. "Pharmacotherapeutic effect of methanolic extract of Telfairia occidentalis leaves on glycemic and lipidemic indexes of alloxan-induced diabetic rats". International Journal of Bio-Science and Bio-Technology 11.8 (2019):1-17.
39. Polenakovic M and Sikole A. "Is erythropoietin a survival factor for red blood cells?". Journal of the American Society of Nephrology 7.8 (1996): 1178-1182.

40. Oyedeji KO., et al. "Effect of methanolic extract of Vernonia amygdalina on haematological and plasma biochemical parameters in male albino rats". Journal of Research in Medical and Dental Science 3.5 (2013): 64-67.

41. American Diabetes Association: Nutrition recommendation and principles for people with diabetes mellitus clinical practice recommendations". Diabetes care 23 (2000): 543-546.

42. Chike CPR., et al. "Effect of Ethanolic Leaf Extract of Vernonia amygdalina (Bitter Leaf) Extract on some of the Haematological Parameters in Wistar Rats". Journal of Complementary and Alternative Medical Research 5.1 (2018): 1-7.

43. Farombi EO. "African indigenous plants with chemotherapeutic potentials and biotechnological approach to the production of bioactive prophylactic agents Afr". Journal of Biotechnology 2.12 (2003):662-671.

44. Ugochukwu NH and Babady NE. "Antihyperglycemic effect of aqueous and ethanolic extracts of Gongronema latifolium leaves on glucose and glycogen metabolism in livers of normal and streptozotocin-induced diabetic rats". Life Sciences 73.15 (2003):1925-1938.

45. Sweeney CJ., et al. "The sesquiterpene lactone parthenolide in combination with docetaxel reduces metastasis and improves survival in a xenograph model of breast cancer". Molecular cancer therapeutics 4.6 (2005): 1004 .

46. Li Y., et al. "Interaction of thrombopoietin with the platelet complements receptor in plasma: binding, internalization, stability and pharmacokinetics". British Journal of Haematology 106.2 (1999): 345-356.

Volume 3 Issue 10 October 2019

(C) All rights are reserved by Augustine I Airaodion., et al. 